K A N D A I

\begin{tabular}{|l|l|l|}
\hline Volume 16 & No. 2, November 2020 & Halaman 149-165 \\
\hline
\end{tabular}

\title{
PRESERVASI NILAI KEARIFAN LOKAL DALAM TRADISI LISAN TEDA MASYARAKAT KABIZU BEIJELLO MELALUI RANAH PENDIDIKAN (Preservation of Local Wisdom Teda Oral Tradition of Kabizu Beijello Community through the Domain of Education)
}

\author{
Yuliana Sesi Bitu \& R. Kunjana Rahardi \\ Universitas Sanata Dharma \\ Jalan Affandi, Mrican, Caturtunggal, Depok, Sleman, Yogyakarta, Indonesia \\ rahardi.kunjana@gmail.com; sesibitu@gmail.com
}

(Diterima: 16 Februari 2020; Direvisi: 28 Agustus 2020; Disetujui: 3 November 2020)

\begin{abstract}
This research has two objectives namely to describe the values of local wisdom contained in the Teda oral tradition at the Padede Uma Kalada ceremony and to formulate a preservation strategy of the Teda oral tradition through the realm of education. The analysis of the value of local wisdom in this study is studied using a metaphorical ecolinguistic perspective. The methods used to collect data are observation, etnography interview methods and literature review. Based on the research results, it was found that there were five values of local wisdom, namely the values of obedience, religion, unity, reconciliation and gratitude. The preservation of local wisdom values in the Teda oral tradition through the realm of education can be done through curricular activities and extracurricular activities. Curricular activities can be carried out through language and literature learning activities as well as local content. Meanwhile, extracurricular activities can be carried out by forming interest and talent groups that include cultural elements in them.

Keywords: Teda Padede Uma Kalada oral tradition, Kabizu Beijello, preservation, local wisdom values, metaphorical ecolinguistics
\end{abstract}

Abstrak

Penelitian ini memiliki dua tujuan yakni mendeskripsikan nilai-nilai kearifan lokal yang terdapat dalam tradisi lisan Teda pada upacara Padede Uma Kalada dan merumuskan strategi preservasi tradisi lisan Teda melalui ranah pendidikan. Analisis nilai kearifan lokal dalam penelitian ini dikaji dengan menggunakan perspektif ekolinguistik metaforis. Metode yang digunakan untuk mengumpulkan data adalah metode simak, wawancara etnografis dan studi pustaka. Berdasarkan hasil penelitian ditemukan lima nilai kearifan lokal, yakni nilai ketaatan, religius, persatuan, rekonsiliasi dan syukur. Upaya preservasi nilai kearifan lokal dalam tradisi lisan Teda melalui ranah pendidikan dapat dilakukan melalui kegiatan kurikuler dan kegiatan ekstrakurikuler. Kegiatan kurikuler dapat dilakukan melalui kegiatan pembelajaran bahasa dan sastra serta muatan lokal. Sementara itu, kegiatan ekstrakurikuler dapat dilakukan dengan membentuk kelompok minat dan bakat yang mengikutsertakan unsur kebudayaan di dalamnya.

Kata-kata Kunci: tradisi lisan Teda Padede Uma Kalada, Kabizu Beijello, preservasi, nilai kearifan lokal, ekolinguistik metaforis

DOI: 10.26499/jk.v16i2.2195

How to cite: Bitu, Y. S., Rahardi, R. K. (2020). Preservasi nilai kearifan lokal dalam tradisi lisan Teda masyarakat Kabizu Beijello melalui ranah pendidikan. Kandai, 16(2), 149-165 (DOI: 10.26499/jk.v16i2.2195) 


\section{PENDAHULUAN}

Pada era globalisasi ini, fenomena tradisi lisan semakin ditinggalkan oleh masyarakat penerusnya (generasi muda). Kondisi seperti ini, apabila tidak disikapi dengan bijak akan menyebabkan kepunahan tradisi lisan serta pudarnya nilai-nilai kearifan lokal yang terdapat di dalamnya. Hal ini sejalan dengan pendapat Supriatin, (2012: 408) yang mengatakan bahwa tradisi lisan merupakan warisan leluhur yang banyak menyimpan kearifan lokal, kebijakan, dan filosofi hidup yang terekspresikan dalam bentuk mantera, petatah-petitih, pertunjukan, dan upacara adat. Situasi seperti ini juga terjadi pada berbagai tradisi lisan yang ada di nusantara, salah satunya adalah tradisi lisan Teda. Tradisi lisan Teda merupakan salah satu tradisi lisan masyarakat Wewea, Sumba Barat Daya.

Tradisi lisan Teda ini selalu dituturkan dalam setiap upacara adat masyarakat Wewea termasuk dalam upacara adat pembangunan Rumah Besar (Rumah Adat dari satu klan). Upacara ini dalam bahasa Sumba biasa disebut Padede Uma Kalada. Berdasarkan hasil percakapan etnografis dengan tetua adat, diketahui bahwa tradisi lisan Teda hanya dikuasai oleh penutur-penutur yang sudah tua. Keterlibatan generasi muda dalam melestarikan tradisi lisan Teda ini sangat minim. Generasi muda lebih tertarik dengan hal-hal yang bersifat modern dibanding mempelajari tradisi lisan Teda, baik mempelajari pengetahuan tentang tradisi lisan Teda maupun menuturkan tradisi lisan Teda tersebut.

Penelitian yang dilakukan Mbete, (2015) membuktikan bahwa ada gejala serius yang melanda sebagian besar generasi muda bangsa yakni "ketercerabutaan" (rootlessness) dari akar lokal. Generasi muda bangsa semakin pragmatis, lebih berorientasi dan memilih untuk mempelajari dan menguasai bahasa asing sehingga mengabaikan bahasa daerah atau bahasa lokal. Tradisi lisan yang menggunakan bahasa daerah juga semakin terasingkan. Selain itu, Kepala Badan Pengembangan Bahasa dan Perbukuan Kementerian Pendidikan dan Kebudayaan, Dadang Sunendar dalam pidatonya pada saat memperingati puncak Bulan Bahasa dan Sastra pada hari Senin (28/10/2019) di Jakarta mengatakan fakta bahwa di wilayah Indonesia, 11 bahasa daerah telah punah, 22 bahasa terancam punah, 4 bahasa dalam kondisi kritis, 16 bahasa stabil, tetapi terancam punah, dan hanya 19 bahasa yang berada pada kategori aman (Kompas, 2019).

Terancam punahnya bahasa daerah dan fenomena kurangnya rasa memiliki dan cinta generasi muda terhadap bahasa daerah akan berimbas pada hilangnya kearifan-kearifan lokal. Selain itu, kondisi ini juga menyebabkan memudarnya nilai-nilai toleransi, solidaritas, dan persatuan yang merupakan warisan leluhur yang terekam dalam tradisi lisan atau bahasa daerah itu. Hal ini senada dengan Mbete (2015: 183) yang menjelaskan bahwa ancaman punahnya bahasa daerah jelas berdampak pada sirnanya nilai-nilai warisan leluhur, adicita (ideology), dan aneka kearifan lokal (local wisdom) yang terekam dalam bahasa lokal itu.

Berdasarkan berbagai fakta dan data di atas, upaya preservasi nilai kearifan lokal pada tradisi lisan Teda khususnya dalam upacara Padede Uma Kalada melalui ranah pendidikan menjadi sebuah keniscayaan dalam konteks globalisasi. Selain sebagai salah satu langkah memelihara dan melestarikan bahasa daerah (tradisi lisan Teda), hal ini juga merupakan salah satu cara menyelamatkan nilai-nilai kearifan lokal yang terekam dalam tradisi lisan 
itu sendiri. Uraian ini sejalan dengan Rahardi (2016) yang mengatakan bahwa dalam konteks globalisasi preservasi dan penyelamatan nilai-nilai kebijaksanaan dan kearifan lokal harus mendapat tempat yang lebih tepat. Sementara itu, Primadesi (2013: 181) mengungkapkan juga bahwa preservasi pengetahuan yang bersifat kearifan lokal dan merupakan pengetahuan asli penting untuk dilakukan dikarenakan hal ini berhubungan dengan lingkungan dan pengembangan sosial budaya masyarakat setempat. Tujuan preservasi nilai kearifan lokal dalam tradisi lisan Teda upacara Padede Uma Kalada melalui ranah pendidikan dalam penelitian adalah agar generasi muda (peserta didik) memiliki rasa cinta terhadap warisan budaya lokal dan memiliki ketertarikan untuk mempelajari, mengembangkan dan menjaga tradisi lisan sebagai warisan nenek moyang agar tetap lestari (Hidayatullah, Riadi, dan Putrawan, 2017).

Setelah melihat berbagai paparan tentang tradisi lisan Teda serta urgensinya untuk dipreservasi melalui ranah pendidikan, peneliti juga akan menjelaskan tentang ekolinguistik metaforis sebagai pisau analisis dalam mendeskripsikan nilai kearifan lokal dalam tradisi lisan Teda. Ekolinguistik metaforis merupakan ilmu yang mengkaji hubungan tali temali antara bahasa dengan strata sosial, status sosial, kebudayaan, etnisitas, laras, dan sejenisnya (Rahardi, 2016). Dalam kajian ekolinguistik metaforis, bahasa yang digunakan dalam tradisi lisan Teda pada upacara Padede Uma Kalada memberikan gambaran terkait nilai-nilai kearifan lokal yang dihidupi oleh masyarakat Kabizu Beijello (salah satu klan yang ada di Wewea, Sumba Barat Daya). Hal itu seperti yang dijelaskan Mbete (2015) bahwa dalam perspektif ekolinguistik, bahasa adalah gambaran tentang realitas, gambaran tentang pengetahuan dan pengalaman manusia.

Berdasarkan seluruh paparan tersebut tujuan penelitian ini adalah (1) mendeskripsikan nilai-nilai kearifan lokal dalam tradisi lisan Teda pada upacara Padede Uma Kalada dengan menggunakan perspektif ekolinguistik metaforis dan (2) mendeskripsikan strategi preservasi yang dapat dilakukan agar tradisi lisan Teda dapat tetap lestari melalui ranah pendidikan.

\section{LANDASAN TEORI}

\section{Tradisi Lisan Teda dalam Upacara Padede Uma Kalada}

Tradisi lisan merupakan tradisi yang berkorelasi dengan fase kehidupan masyarakat sebelum mengenal kegiatan tulis-menulis. Tradisi ini merupakan salah satu media pewarisan atau transformasi nilai, norma, dan hukum yang pewarisannya berlangsung dari satu generasi ke generasi berikutnya dengan media lisan (Supriatin, 2012). Kelisanan ini tidak hanya fokus pada komunikasi verbal saja, tetapi juga aspek komunikai nonverbal dalam masyarakat, seperti ritual-ritual adat dan pertunjukan (Takari, 2013). Pengertian ini memberi pemahaman bahwa tradisi lisan merupakan salah satu bentuk kebudayaan yang sudah mengakar sejak dulu karena saling berkaitan dengan upacara-upacara adat dalam masyarakat serta menyimpan berbagai nilai luhur yang hendak diwariskan oleh nenek moyang.

Salah satu tradisi lisan yang ada di Indonesia adalah tradisi lisan Teda. Berdasarkan hasil percakapan etnografis, diketahui bahwa Teda adalah ungkapanungkapan tradisional yang sangat magis dan berbernas yang berasal dari Sumba Barat Daya. Ungkapan-ungkapan dalam tradisi lisan Teda memiliki sistem 
pembarisan tersendiri yang berbentuk syair dan selalu diungkapkan dalam konteks upacara adat, seperti upacara adat kelahiran, perkawinan, kematian serta pembangunan "Rumah Besar" (istilah yang digunakan untuk merujuk Rumah Adat). Dalam penelitian ini, peneliti fokus mengkaji tentang tradisi lisan Teda yang dituturkan dalam upacara adat pembangunan "Rumah Besar" atau biasa disebut Padede Uma Kalada oleh anggota masyarakat Kabizu Beijello. Berdasarkan hasil wawancara etnografis diketahui bahwa Kabizu merupakan kelompok kekerabatan yang berasal dari satu nenek moyang dan antara satu dan lainnya terikat melalui garis keturunan ayah. Konsep ini mengindikasian bahwa Kabizu merupakan klan dan Kabizu Beijello merujuk pada salah satu klan yang berada di Kecamatan Wewea, Sumba Barat Daya.

\section{Nilai Kearifan Lokal}

Kearifan lokal adalah gagasangagasan lokal, pengetahuan setempat atau kecerdasan setempat yang bersifat bijaksana, penuh kearifan, bernilai, dan diikuti oleh warga masyarakat sehingga menjadi dasar identitas kebudayaan (Kartawinata, 2011). Hal ini juga sejalan dengan Sriyono (2014: 57) yang mengatakan bahwa kearifan lokal merupakan pengetahuan lokal yang digunakan masyarakat lokal untuk bertahan hidup dalam lingkungan yang menyatu dengan sistem kepercayaan, norma, dan budaya yang diekspresikan dalam tradisi dan mitos yang dianut dalam jangka waktu yang lama.

Kearifan lokal ini merupakan cermin realitas masyarakat yang dapat ditelusuri melalui berbagai tradisi yang ada di masyarakat (termasuk tradisi lisan). Di dalam kearifan lokal tersebut, terdapat nilai-nilai luhur yang diwariskan nenek moyang demi menata kehidupan bermasyarakat. Nilai kearifan lokal dapat dipahami sebagai sesuatu yang berharga dan ideal (dari kearifan lokal) yang memberikan corak pada pola pikir, perasaan, dan perilaku (Aslan, 2017). Uraian ini mengindikasikan bahwa nilai kearifan lokal lekat dengan kebudayaan dalam masyarakat dan melalui nilai ini pula, masyarakat yang berbudaya menata kehidupan sosial, ekomoni, dan budaya masyarakat mereka.

\section{Preservasi Melalui Ranah Pendidikan}

Dalam KBBI (2016), preservasi
$\begin{aligned} & \text { diartikan sebagai pengawetan, } \\ & \text { pemeliharaan, penjagaan, dan }\end{aligned}$
perlindungan. Hal ini juga sejalan dengan Elis yang mengatakan bahwa preservasi adalah tindakan yang memungkinkan tradisi lisan dapat dipertahankan dalam jangka waktu yang lama melalui kegiatan perlindungan dan pemeliharaan tradisi lisan (Elis dalam Kami, 2018: 15). Upaya preservasi ini tepat untuk dilakukan dalam kaitannya dengan menjaga agar tradisi lisan Teda masyarakat Wewea, Sumba Barat Daya tetap lestari begitu pula dengan bahasa daerah serta nilai-nilai kearifan lokal di dalamnya. Hal ini tentu beralasan karena preservasi mencakup semua pertimbangan manajerial, teknik, dan metode pelestarian bahan untuk menjaga informasi yang terkandung di dalamnya (Endang, 2018).

Selain itu, preservasi nilai ini termasuk dalam jenis preservasi pengetahun, yakni upaya preservasi yang berhubungan dengan lingkungan dan pengembangan sosial budaya masyarakat (Primadesi, 2013). Berdasarkan berbagai uraian tersebut, maka preservasi melalui lembaga pendidikan dapat diartikan sebagai upaya penjagaan dan pemeliharaan tradisi lisan beserta nilai- 
nilai yang terkandung di dalamnya melalui lembaga pendidikan di setiap tataran, baik secara eksplisit sebagai sebuah mata pelajaran maupun implisit dalam berbagai mata pelajaran dan kegiatan ekstrakurikuler.

\section{Ekolinguistik Metaforis}

Ekolinguistik merupakan teori yang dipelopori oleh Haugen pada tahun 1972. Teori ini merupakan bentuk kritik Haugen terhadap para pakar bahasa yang pada umumnya lebih banyak membicarakan permasalahanpermasalahan bahasa yang berkaitan dengan sisi internal bahasa (mikrolinguistik), seperti fonologi, sintaksis, dan leksikon (Haugen, 1972). Dalam pandangan Haugen, penelitian ekologi bahasa (ekolinguistik) dapat lebih luas dan memberi ruang untuk bekerja sama dengan ilmu-ilmu lain seperti antropologi, sosiologi, politik dan psikologi. Atas dasar pemikiran tersebut, Haugen menciptakan paradigma baru dalam kajian bahasa, yakni ekologi bahasa. Ekolinguistik atau ekologi bahasa merupakan studi tentang interaksi bahasa tertentu dengan lingkungannya (Haugen, 1972). Lingkungan dalam hal ini didefinisikan sebagai masyarakat yang menggunakan bahasa sebagai salah satu kode.

Ekolinguistik merupakan studi multidisipliner bahasa dalam interaksi yang menafsirkan bahasa dalam hal adat istiadat, budaya, strata sosial, sudut pandang politik, dan bentuk-bentuk lain yang khas pada lingkungan tertentu. Ini adalah tren mengenai keterkaitan antara bahasa dalam pikiran (jumlah total dari pengetahuan dan pengalaman) dan dalam masyarakat multibahasa (Uyanne, Onuoha, dan Osigwe, 2014). Konsep yang dikemukakan di atas merujuk pada ekolinguistik dalam pengertian metaforis. Hal itu ditegaskan oleh
Rahardi, Setyaningsih, dan Rishe Purnama Dewi (2016) yang mengatakan bahwa ekologi bahasa pada gilirannya bermetamorfosis menjadi ekolinguistik, baik dalam pengertian natural maupun metaforis. Studi ekolinguistik natural kini banyak disebut envirolinguistik, yakni berbagai dimensi alam yang bertali temali dengan bahasa yang selanjutnya melahirkan konsep ikonisitas. Sedangkan dimensi ekolinguistik lainnya bersifat metaforis dan lazim diterminologikan sebagai ekolinguistik metaforis, yakni hubungan tali temali antara bahasa dengan strata sosial, status sosial, kebudayaan, etnisitas, laras dan sejenisnya. Dalam hal ini, bahasa yang digunakan oleh masyarakat atau suatu komunitas merupakan tuturan yang memberikan gambaran terkait, kearifan lokal, nilai, norma, adat istiadat, dan budaya yang dihidupi oleh masyarakat atau komunitas itu.

Steffensen dan Fill (2013: 3) mengemukakan bahwa ada empat pendekatan dalam ekolinguistik, yakni (1) bahasa terdapat ekologi simbolik (menyelidiki hubungan antara simbolsimbol dalam bahasa dengan lingkungan sekitar); (2) bahasa ada dalam ekologi alamiah (menyelidiki penggunaan bahasa dengan lingkungan alamiah); (3) bahasa ada dalam ekologi sosiokultural (menyelidiki hubungan bahasa dengan kekuatan sosial dan budaya yang membentuk kondisi penutur dan komunitas tutur); dan (4) bahasa ada dalam ekologi kognitif (menyelidiki hubungan bahasa dengan pengetahuan yang dimiliki penutur). Berdasarkan uraian tersebut, diketahui bahwa pendekatan bahasa dalam dalam ekologi simbolik, kognitif, dan sosiokultural termasuk dalam kajian ekolinguistik metaforis, tetapi dengan mempertimbangkan hubungan bahasa dengan ekologi alamiah. 


\section{METODE PENELITIAN}

Penelitian ini termasuk dalam jenis penelitian kualitatif. Data dalam penelitian ini diperoleh dari dua jenis sumber data, yakni sumber data lokasional dan sumber data substantif (K. Rahardi, 2009). Sumber data lokasional dalam penelitian ini adalah masyarakat Kabizu Beijello yang berdomisili dikecamatan Wewewa Barat, Kabupaten Sumba Barat Daya, Nusa Tenggara Timur. Sementara itu, sumber data substantif dalam penelitian ini adalah tuturan dalam tradisi lisan Teda pada upacara Padede Uma Kalada yang telah ditranskripsi peneliti menjadi teks dari hasil rekaman atau hasil catatan pada saat pengumpulan data.

Data dalam penelitian ini terdiri atas dua jenis data, yakni data primer dan data sekunder. Data primer dalam penelitian ini adalah bagian dari tuturan tradisi lisan Teda yang mengandung nilai-nilai kearifan lokal masyarakat Kabizu Beijello sedangkan data sekunder dalam penelitian ini adalah informasi tambahan yang diperoleh peneliti dari hasil wawancara etnografis dengan informan, hasil studi dokumen dan referensi-referensi pustaka yang dikutip oleh peneliti untuk mengonfirmasi dan mengaskan hasil interpretasi data primer yang diteliti.

Metode dan teknik pengumpulan data dalam penelitian ini menggunakan metode simak dengan teknik rekam, metode etnografi komunikasi, dan studi pustaka. Metode simak merupakan salah satu metode pengumpulan data dengan cara menyimak penggunaan bahasa dan metode ini dapat disejajarkan dengan metode pengamatan atau observasi dalam ilmu sosial (Sudaryanto, 2015). Dalam penelitian ini, metode simak dengan metode rekam digunakan saat peneliti hendak merekam setiap tuturan dalam tradisi lisan Teda pada upacara
Padede Uma Kalada. Selanjutnya, metode etnografi dianggap tepat untuk digunakan karena metode ini berusaha memberikan pemahaman tanpa distorsi dan berangkat dari pemahaman budaya masyarakat yang ingin dipahami dan bukan dari asumsi peneliti (Spradley, 2007). Penggunaan metode etnografi digunakan dalam penelitian ini karena, penggunaan bahasa dalam tradisi lisan Teda tidak dapat dilepas dan dipisahkan dengan budaya masyarakat setempat. Analisis data dalam penelitian ini dilakukan dengan metode padan ekstralingual (Mahsun, 2005) dengan teknik kontekstual (Rahardi, 2009).

\section{PEMBAHASAN}

Sejalan dengan tujuan penelitian, berikut adalah deksripsi nilai kearifan lokal yang terdapat dalam tradisi lisan Teda masyarakat Kabizu Beijello, Wewea, Sumba Barat Daya yang dikaji dengan menggunakan perspektif ekolinguistik metaforis dan deskripsi upaya preservasi nilai kearifan lokal tersebut melalui ranah pendidikan.

\section{Nilai Kearifan Lokal yang Terdapat dalam Tradisi Lisan Teda}

Berdasarkan hasil analisis data ditemukan bahwa dalam tradisi lisan Teda pada upacara Padede Uma Kalada terdapat tuturan (kode-kode bahasa) yang memberikan gambaran terkait nilai-nilai kearifan lokal yang dihidupi oleh masyarakat Kabizu Beijello. Hal itu seperti yang dijelaskan oleh Mulyadi (2014: 93) bahwa di dalam ekolinguistik, bahasa bukan sekadar nomenklatur (tata nama), tetapi bahasa memiliki perangkat kata tertentu sebagai petunjuk bahwa kata-kata itu menjadi bagian yang penting dalam sebuah kebudayaan. Pandangan hidup suatu bangsa adakalanya diungkapkan dengan kata- 
kata kunci tertentu. Seiring dengan itu, nilai-nilai kearifan lokal yang terdapat dalam tradisi lisan Teda pada upacara Padede Uma Kalada adalah nilai ketaatan, religius, persatuan, rekonsiliasi, dan syukur. Masing-masing temuan nilai itu dipaparkan sebagai berikut.

\section{Nilai Ketaatan}

Ketaatan memiliki makna senantiasa tunduk, patuh, setia, dan tidak berlaku curang kepada pemerintah, Tuhan, dan sebagainya (Sukmayadi, 2018). Masyarakat Kabizu Beijello adalah masyarakat yang menganut kepercayaan Marapu. Marapu merupakan sebuah agama asli nusantara yang dianut oleh hampir sebagian masyarakat di Pulau Sumba dan merupakan nama sebuah organisasi penghayat kepercayaan yang telah didaftarkan pada tahun 1982. Marapu diyakini mampu memberikan pertolongan dan berkat. Selain itu, kepercayaan Marapu juga dijadikan sebagai landasan tata nilai dan kunci kehidupan masyarakat Kabizu Beijello. Menyadari hal itu, masyarakat Kabizu Beijello selalu menunjukkan sikap taat dan patuh kepada Marapu. Hal itu terekspresikan dalam data berikut.

\section{Data 1}

Nebahinna, nennatipamamaole

'saat ini, ini sirih pinang kawan'

(terimalah sirih pinang ini).

Mandungokatanga, ketterakaleba

'pegang kuat kendali, eratkan ikat pinggang'

(peganglah kuat-kuat keputusan dan janji yang telah disepakati bersama).

Tanadadikki, watudangero

'tanah yang tidak berpindah, batu yang tidak bergeser'

(keputusan dan janji yang tidak akan berubah).

\section{Konteks:}

Tuturan tersebut merupakan bagian dari tradisi lisan Teda saat pembagian sirih pinang ketika pertemuan satu keluarga besar Kabizu Beijello di rumah besar (salah satu tahap dalam upacara Padede Uma Kalada). Data di atas dituturkan oleh pemimpin klan atau orang yang dipercayakan pemimpin musyawarah pada tahap musyawarah adat satu keluarga besar Kabizu Beijello di rumah besar.

Data tersebut memperlihatkan adanya peristiwa pembagian sirih pinang setelah pengambilan ikrar atau sumpah. Sirih pinang diyakini sebagai simbol kehadiran Marapu (arwah-arwah leluhur) yang mengikat seluruh keputusan yang telah disepakati. Oleh karena itu, keputusan itu tidak boleh dilanggar dan jika dilanggar akan mendatangkan petaka.

Pada data 1, terdapat kearifan lokal berwujud nyata yang ditunjukkan melalui kata pamama 'sirih-pinang'. Dalam bahasa Wewewa, sirih disebut utta, sedangkan pinang disebut winno, tetapi masyarakat Wewewa pada umumnya termasuk masyarakat Kabizu Beijello pada saat menyebut buah sirih dan pinang secara bersamaan selalu menggunakan kata pamama. Pamama dalam data 1 mengandung makna simbolik karena secara konvensional, pamama 'sirih-pinang' diakui bersama oleh masyarakat Kabizu Beijello sebagai lambang kehadiran Marapu yang mengikat dan mengesahkan ikrar yang diangkat dalam musyawarah adat.

Dalam budaya masyarakat Kabizu Beijello, ikrar yang diangkat melalui sumpah adat yang ditandai dengan pembagian sirih pinang tidak boleh dilanggar. Petaka bagi yang melanggarnya. Dengan demikian, pamama sebagai simbol dalam ritual adat Padede Uma Kalada memiliki daya kekuatan yang mampu mempengaruhi 
pikiran dan tindakan masyarakat Kabizu Beijello. Hal ini sejalan dengan Dharmojo (2005: 28) yang menjelaskan bahwa simbol mempunyai daya kekuatan yang dapat merangsang perasaan dan tindakan seseorang. Simbol berpartisipasi dalam makna dan kekuatan dari sesuatu yang disimbolkan.

Nilai yang dapat direfleksikan melalui peristiwa pembagian pamama 'sirih-pinang' dalam konteks data 1 adalah ketaatan terhadap hukum adat. Dalam budaya masyarakat Kabizu Beijello, setiap orang yang telah melakukan sumpah adat yang ditandai dengan penerimaan sirih pinang tidak boleh melanggar sumpah tersebut. Menerima sirih pinang berarti sumpah yang diambil telah diikat dan disahkan oleh Marapu. Oleh karena itu, setiap keputusan yang telah diikat oleh sumpah adat itu harus ditaati dan dijalankan dengan penuh kesetiaan, kejujuran dan tanggung jawab. Hal itu digambarkan pula pada metafora mandungo katanga, ketera kaleba, yang apabila diterjemahkan secara cermat memiliki arti 'pegang kuat kendali, eratkan ikat pinggang'. Maknanya, setiap orang yang telah menerima sirih pinang harus memegang erat keputusan bersama tersebut. Hal ini terjadi karena keputusan itu bersifat sah, kukuh, dan mengikat. Hal itu ditunjukkan pula pada metafora tana dadikki, watu ndangero 'tanah yang tidak berpindah, batu yang tidak bergeser' yang memiliki makna bahwa sumpah adat itu bersifat sah dan mengikat. Pelanggaran diyakini dapat membawa petaka bagi orang yang melanggar keputusan itu.

Senada dengan hal di atas, Aluman (2016) menemukan bahwa komunitas Marapu memiliki komitmen yang sangat tinggi terhadap sebuah keputusan. Penghargaan terhadap sebuah keputusan diwujudkan dalam pelaksanaannya. Masyarakat Marapu tidak mengingkari janji atau melaksanakan sesuatu hal yang menyimpang dari keputusan yang ditetapkan sebelumnya. Keputusan yang telah ditetapkan memiliki nilai yang sangat tinggi dan mengandung risiko buruk ketika dilanggar dalam pelaksanaannya.

\section{Nilai Religius}

Religi bersinonim dengan kepercayaan, yakni kepercayaan kepada Tuhan dan kepercayaan akan adanya kekuatan adikodrati yang melampaui kemampuan manusia. Kepercayaan itu selama ini dikenal sebagai kepercayaan animisme dan dinamisme (Bera, 2016). Masyarakat Kabizu Beijello sebagai masyarakat Marapu tidak hanya percaya kepada Marapu atau kekuatan gaib yang lainnya, tetapi juga memiliki kepercayaan kepada wujud tertinggi, yakni Tuhan yang Maha Esa. Penggambaran dan penanaman nilai religius ini juga digambarkan dalam tradisi lisan Teda dalam upacara adat Padede Uma Kalada melalui data berikut.

\section{Data 2}

Nadukkiwe na'i labe a belleka, Pari'i A Kaladana

'sampai kepada dia di sana, cincin yang lebar dan tiang yang besar'

(Sampai kepada Sang Khalik).

A kanga wollalimma, A bokka wollawa'i 'yang memisah jari tangan, yang membagi jari kaki'

(Tuhan yang memisahkan jari tangan dan jari kaki).

Ina A Mawol, Ama A Marawi

'ibu yang mencipta, bapak yang menjadikan'

(Tuhan yang menjadikan, menciptakan manusia, dan seluruh alam semesta).

Adopola tou, A adiwe wekki

'yang membentuk badan, yang memadatkan tubuh' 
(Tuhan yang membentuk dan memadatkan badan).

\section{Konteks:}

Tuturan lisan tersebut merupakan bagian dari tradisi lisan pada tahap Saiso (istilah saat tradisi lisan Teda dituturkan dengan cara dinyanyikan) pembuatan loteng rumah. Data tradisi lisan ini dinyanyikan oleh Ata Saiso (istilah untuk menyebut penutur Saiso). Nyanyian ini merupakan doa yang ditujukan kepada Tuhan melalui perantaraan Marapu. Dalam doa itu, Ata Saiso memohon pengampunan, keselamatan, dan keberhasilan pembuatan loteng rumah.

Pada data 2, terdapat kearifan lokal berwujud nyata (tangible), yakni cincin dan tiang pada tuturan labe a belleka, pari'iakaladana (cincin yang lebar, tiang yang besar). Data ini mengandung makna simbolik yang secara konvensional diakui bersama oleh masyarakat Kabizu Beijello sebagai lambang kehadiran Tuhan Yang Mahabesar dan Mahaagung.

Masyarakat Kabizu Beijello memiliki struktur rumah adat yang ditopang oleh empat tiang utama. Masing-masing tiang tersebut memiliki labe 'cincin' yang merupakan kayu berbentuk bulat. Dari keempat pari' $i$ dan labe ini terdapat salah satu pari' $i$ yang dimaknai sebagai Tiang Agung yang dalam bahasa Wewewa disebut koko poga. Masyarakat Kabizu Beijello memandang Tiang Agung sebagai Tuhan-Allah, Tuhan Yang Mahabesar dan Mahaagung. Tiang Agung melambangkan kehadiran Tuhan yang menjadi tempat untuk bersandar, memohon berkat, dan menopang seluruh umatnya.

Sementara itu, labe yang ada pada Tiang Agung itu diyakini sebagai mazbah Tuhan, sebagai tempat bertahta dan kedudukan Tuhan. Labe melambangkan Tuhan yang dapat memayungi, melindungi, dan menaungi umatnya. Dengan demikian, pari'i dan labe bagi masyarakat Kabizu Beijello tidak hanya dipandang sebagai penyangga atap saja, tetapi mengandung nilai filosofis, yakni menandakan masyarakat yang religius meyakini dan percaya akan keberadaan Tuhan sebagai pencipta, penjaga dan penyelenggara kehidupan. Hal ini sejalan dengan Bera (2016: 193) yang mengungkapkan bahwa tiang utama atau tiang besar orang Sumba disebut sebagai Tiang Agung. Ungkapan ini tertuju pada pengertian kehadiran Tuhan Pencipta yang memikul dan melindungi seluruh umat manusia. Cincin menjadi payung yang menaungi seluruh manusia.

Masyarakat Kabizu Beijello sesungguhnya mempunyai cara yang sangat sederhana, tetapi jitu dalam menanamkan nilai-nilai kehidupan baik sebagai warga rumah maupun sebagai warga Kabizu. Masyarakat Kabizu Beijello dalam membangun kesadaran hidup berketuhanan, Tuhan Sang Pencipta itu dihadirkan atau digambarkan melalui benda-benda fisik tertentu berupa bagian dari tubuh rumah sebagai simbol. Pencipta disimbolkan dengan Pari'i Kalada atau Tiang Besar dan Labe A Belleka atau Cincin Yang Lebar. Arti praktisnya adalah Tuhan Pencipta itu adalah pelindung hidup manusia warga rumah maupun warga Kabizu. Tuhan adalah sandaran dan andalan seperti tiang pada rumah menjadi penopang bangunan rumah. Sementara itu, cincin yang lebar itu memiliki makna Tuhan sebagai penopang dan pemberi kekuatan seperti cincin yang melekat pada tiang itu merupakan penopang dan penguat bangunan rumah. Melalui benda simbolik Tiang Agung dan Cincin Yang Lebar yang kelihatan terjadi sebuah didikan dan transfer nilai bahwa Tuhan Sang Pencipta sungguh ada dan hadir di 
dalam dan di tengah hidup manusia (Ramone, 2015).

Pengakuan akan adanya Tuhan Sang Khalik selain ditunjukkan melalui benda-benda simbolik juga senantiasa dinyatakan dengan nama-nama paralel dan kalimat-kalimat kiasan. Hal itu seperti yang ditunjukkan pada data 2, yakni "Yang memisah jari tangan, Yang memisah jari kaki. Ibu yang mencipta, Bapak yang menjadikan. Yang membentuk badan, Yang memadatkan tubuh". Dalam catatan Neonbasu (2016: 95), kalimat-kalimat kiasan ini digunakan untuk menggambarkan secara kurang lebih tepat hakekat ilahi sebagai subjek spiritual kosmis yang menciptakan semua dari ketiadaan. Gelar-gelar ini langsung tertuju pada fungsi sentral dan hakikat Yang Tertinggi.

Data 2 membuktikan bahwa bahasa merepresentasikan lingkungan sosial dan budaya masyarakat penuturnya. Sistem simbolik pada tuturan-tuturan dalam tradisi lisan Teda pada upacara Padede Uma Kalada memberikan gambaran terkait lingkungan sosial budaya masyarakat Kabizu Beijello sebagai pemilik bahasa sekaligus budaya tersebut. Hal ini sejalan dengan Duranti (1997: 2) yang menjelaskan bahwa melalui bahasa terungkap kebudayaan yang di dalamnya terlihat seluk beluk kehidupan manusia dan berbahasa merupakan performa aktivitas sosial dan budaya.

\section{Nilai Persatuan}

Makna persatuan pada hakikatnya adalah satu, yakni bulat dan tidak terbagikan atau terpecah belah (Asmaroini, 2017: 58). Masyarakat Kabizu Beijello merupakan salah satu masyarakat etnis di Pulau Sumba yang sangat memelihara nilai persatuan dalam kehidupan bersama. Nilai tersebut tampak jelas dalam tuturan pada tradisi lisan Teda dalam upacara Padede Uma Kalada berikut.

\section{Data 3}

Kada'ikanaa lera ekabei, akeduekaana 'agar tidak ada yang terbang lain ibu, yang lari lain anak'

(agar kita selalu membina semangat persatuan).

Katta pasamana ate, katta pamerana wiwi

'agar kita menyamakan hati, agar kita memerahkan bibir'

(agar kita selalu satu hati, satu suara).

\section{Konteks:}

Tuturan lisan tersebut merupakan bagian dari tradisi lisan pada tahap musyawarah satu keluarga besar Kabizu Beijello di rumah besar (rumah adat). Tuturan lisan tersebut dituturkan oleh tetua adat yang menjaga rumah besar. Tetua adat itu merupakan pemimpin klan Beijello. Musyawarah yang diadakan di rumah besar ini merupakan musyawarah terakhir sebagai penentu keputusan dan sekaligus pembagian tugas pembangunan rumah besar. Musyawarah ini diikuti oleh tetua adat rumah besar, tetua-tetua adat rumah kecil, dan anggota-anggota Kabizu Beijello yang mempunyai pemikiran yang luas, cakap, berani, dan berjiwa kepemimpinan. Dalam musyawarah itu, tetua adat menghimbau agar seluruh anggota keluarga selalu bersatu, sehati, sesuara demi suksesnya pembangunan rumah besar.

Kearifan lokal yang terdapat pada data 3 adalah kearifan lokal yang berwujud tidak nyata (intangible), berbentuk petuah. Petuah pada data 3 menggambarkan salah satu nilai luhur yang selalu dihidupi oleh masyarakat Kabizu Beijello, yakni persatuan. Petuah tersebut selalu digunakan oleh orang tua atau pemimpin pada saat memberikan 
wejangan untuk selalu menjaga persatuan. Kata "ibu" pada petuah "agar tidak ada yang terbang ke lain ibu" merujuk pada pemimpin klan. Sementara itu, kata "anak" pada petuah "agar tidak ada yang lari ke lain anak" merujuk pada anggota masyarakat Kabizu Beijello. Tuturan ini merupakan imbauan kepada warga masyarakat Kabizu Beijello agar tidak membelot kepada pemimpin klan yang lain. Begitu pun pemimpin klan Kabizu Beijello agar tidak membelot kepada warga Kabizu lain. Wejangan yang hendak disampaikan melalui petuah ini adalah agar seluruh anggota keluarga tidak berjalan sendiri-sendiri dan agar tidak ada yang tercerai berai sehinga seluruh anggota Kabizu Beijello selalu menjaga persatuan demi terwujudnya kesuksesan.

Dalam kebudayaan masyarakat Kabizu Beijello, diyakini bahwa kesuksesan hanya akan tercapai apabila nilai persatuan dijunjung tinggi. Sementara itu, petuah katta pasamana ate 'agar kita satu hati', katta pamerana wiwi 'agar kita memerahkan bibir' mengandung pesan agar seluruh anggota keluarga Kabizu Beijello bersatu hati, bersatu suara, seia sekata dalam mendukung, dan melaksanakan kesepakatan dalam musyawarah tersebut demi suksesnya pembangunan rumah adat. Hal ini juga dipertegas melalui wawancara dengan informan yang mengatakan bahwa petuah yang terkadung di dalam tradisi lisan Teda, Padede Uma Kalada, tersebut megandung nilai persatuan. Petuah ini selalu digunakan oleh orang tua, orang bijak, dan pemimpin pada saat memberikan amanat dan nasihat agar masyarakat senantiasa selalu bersamasama pada saat bekerja dan bergotong royong dalam mensukseskan suatu pekerjaan. Nilai persatuan dalam hal ini juga bukan semata-mata hanya dalam hal bekerja sama pada saat membangun rumah adat saja, tetapi juga dalam kehidupan bermasyarakat secara umum.

\section{Nilai Rekonsiliasi}

Rekonsiliasi dapat diartikan sebagai upaya untuk memperbaiki hubungan sosial yang hasil akhirnya adalah perdamaian (Gogalai, 2008 dalam Nugraha, 2019). Rekonsiliasi juga diartikan sebagai perbuatan memulihkan persahabatan ke keadaan semula (KBBI, 2016). Dalam konteks penelitian ini, rekonsiliasi merupakan suatu upaya untuk untuk memulihkan hubungan dengan cara meminta maaf atau memohon pengampunan sebagai konsekuensi atas pelanggaran yang dilakukan. Dalam kehidupan spiritual masyarakat Kabizu Beijello, rekonsiliasi merupakan hal yang wajib dilakukan ketika melakukan pelanggaran terhadap perintah Marapu (roh leluhur). Hal itu seperti dieksplisitkan dalam data tradisi lisan Teda pada upacara Padede Uma Kalada berikut.

\section{Data 4 \\ Lakkawa'ikunamme adiraka pababa touna, aakita paleira wekkina \\ 'kendatipun ada yang beraib tubuhnya, berdosa badannya' \\ (kendatipun ada yang memiliki aib dan dosa). \\ Du kettekageole, du pagukawipangngu \\ 'janganlah ikat bersama, jangan simpul bergandeng' \\ (janganlah engkau melibatkannya dengan kami).}

\section{Konteks:}

Data ini merupakan bagian dari data tradisi lisan pada tahap Saiso sebelum membuat loteng rumah. Data dituturkan oleh Ata Urrata (istilah untuk penutur tradisi lisan Teda). Data ini merupakan doa kepada nenek moyang agar masyarakat Kabizu Beijello memperoleh 
khidmat, keselamatan, pengampunan, dan keberhasilan kepada nenek moyang.

Kearifan lokal pada data 4 adalah kearifan lokal yang berwujud tidak nyata (intangible) berupa paralelisme, yaitu lakkawa'ikunamme adiraka pababa touna, aakita paleira wekkina 'kendatipun ada yang beraib tubuhnya, berdosa badannya' dan Du kettekageole, $d u$ pagukawipangngu 'jangan ikat bersama, jangan simpul bergandeng'. Maknanya, pengampunan bagi anggota masyarakat Kabizu yang telah melanggar perintah Marapu. Berdasarkan konteks data, kedua tuturan ini dituturkan dalam ritual Saiso sebelum membuat loteng rumah. Masyarakat Kabizu Beijello memaknai ritual Saiso sebelum membuat loteng rumah sebagai ritual untuk memohon pertolongan, perlindungan, dan keselamatan kepada Marapu sekaligus memohon pengampunan untuk anggota Kabizu yang melanggar perintah Marapu. Dengan demikian, ritual Saiso dimaknai juga sebagai ritual rekonsiliasi dengan Marapu.

Dalam ritual itu, Ata Saiso memohon kepada Marapu agar pada saat membuat loteng rumah anggota keluarga adirraka pababa touna 'yang beraib tubuhnya, yang berdosa badannya' dan aakita paleira wekkina 'yang tidak bersih dirinya, yang melakukan perbuatan yang menyimpang dari amanat Marapu seperti mencuri, berzinah, bersaksi dusta, dan membunuh' agar diampuni. Hal itu dilukiskan pada tuturan $d u$ kettekageole, $d u$ pagukawipangngu 'janganlah ikat bersama, jangan simpul bergandeng'. Tuturan ini merujuk pada permohonan agar Marapu tidak melihat kembali kesalahan dari anggota keluarga yang turut ambil bagian dalam proses pembuatan loteng rumah sehingga seluruh proses pembuatan rumah dapat berjalan dengan lancar dan berhasil.
Seiring dengan itu, kehormatan dan nama baik Kabizu Beijellopun ikut terjaga.

\section{Nilai Syukur}

Syukur merupakan salah satu dari kajian psikologi positif yang memiliki arti mengucapkan terima kasih atas anugerah (Shobihah, 2014). Masyarakat Kabizu Beijello senantiasa menanamkan nilai syukur dalam kehidupan seharihari. Ketika seseorang mendapatkan pertolongan apapun bentuknya, maka sepatutnyalah orang tersebut mengucapkan terima kasih. Hal itu terlukiskan dalam data tradisi lisan Teda dalam upacara Padede Uma Kalada berikut.

\section{Data 5}

Pamalangiwa inna, paosawa ama 'terima kasih kepada ibu, syukur kepada bapak'

(terima kasih dan syukur kepada rumah besar dan leluhur)

\section{Konteks:}

Tuturan tersebut merupakan bagian dari tradisi lisan dalam upacara Woleka (salah satu tahap dalam Padede Uma Kalada) atau pembongkaran rumah lama. Tuturan tersebut dinyanyikan oleh Ata Saiso dengan diiringi gong dan tambur. Upacara Woleka dimaknai sebagai upacara pengucapan syukur dan terima kasih kepada nenek moyang dan rumah besar yang telah melindungi, memayungi, mempersatukan, dan memberikan kenyamanan, serta kedamaian. Upacara ini dilaksanakan dengan penuh sukacita dan kegembiraan.

Kearifan lokal yang terdapat pada data 5 adalah kearifan lokal berwujud tidak nyata, yakni petuah pamalangiwa inna, paosawa ama 'terima kasih kepada ibu, syukur kepada bapak. Kata inna dan ama dalam data tersebut tidak hanya 
bermakna 'ibu' dan 'bapak', tetapi merujuk pada semua orang yang telah memberikan pertolongan. Dengan demikian, nilai luhur yang dapat direfleksikan melalui wejangan ini adalah jangan lupa mengucap syukur dan terima kasih dan kepada inna 'ibu' dan ama 'bapak', serta kepada setiap orang yang telah memberikan pertolongan dan bantuan.

Masyarakat Kabizu Beijello tidak hanya mengucap syukur dan terima kasih kepada sesama manusia saja, tetapi juga dengan Sang Pencipta, Marapu, dan rumah yang telah memberikan perlindungan. Hal ini juga didukung dengan konteks data yang menunjukkan bahwa sebelum membongkar rumah adat yang lama, masyarakat Kabizu Beijello melakukan ritual Woleka (ritual syukur). Dengan demikian, petuah tersebut mengandung wejangan, yakni jangan lupa untuk mengucap terima kasih dan syukur kepada Marapu dan rumah yang diyakini telah melindungi, menolong, dan menganugerahkan berkat kepada anggota keluarga yang mendiami rumah besar dan seluruh keluarga besar Kabizu Beijello. Hal ini juga didukung dengan hasil wawancara dengan informan yang memberikan kesaksian bahwa tuturan pamalangiwa inna, paosawa ama memiliki makna bahwa dalam hidup jangan lupa bersyukur dan berterima kasih. Mengucap syukur dan terima kasih merupakan nilai luhur warisan nenek moyang yang mengingatkan kita bahwa kita telah mendapatkan pertolongan dan bantuan.

\section{Strategi Preservasi Tradisi Lisan Teda dalam Upacara Padede Uma Kalada Melalui Ranah Pendidikan}

Preservasi merupakan upaya pemeliharaan tradisi lisan karena di dalam tradisi tersebut terkadung tata nilai yang sangat kaya untuk kehidupan masyarakat (Wirajaya, 2016). Preservasi dalam penelitian ini merupakan upaya yang dapat dilakukan untuk memelihara dan melindungi tradisi lisan Teda. Upaya ini dilakukan melalui ranah pendidikan dan dianggap penting. Preservasi melalui ranah pendidikan diambil karena penanaman nilai bisa dilakukan dengan lebih terorganisasi. Hal ini sejalan dengan pendapat Afiqoh, Atmaja, \& Saraswati, (2018: 42) yang mengatakan bahwa pendidikan bukan hanya mengajarkan memahami materi, tetapi juga pembentukan sikap dan media dalam melestarikan kebudayaan daerah. Penanaman nilai kearifan lokal melalui pendidikan penting diterapkan karena dapat dijadikan sebagai sarana bagi peserta didik untuk lebih mengerti dan mencintai budaya yang dimilikinya.

Masyarakat Kabizu Beijello, terutama generasi muda, tidak semuanya memiliki pengetahuan dan kemampuan dalam menuturkan tradisi lisan Teda. Jika kondisi ini terus diabaikan, kepunahan tradisi lisan Teda dan hilangnya nilai-nilai kearifan lokal yang terekam dalam tradisi lisan itu menjadi sebuah kenyataan yang tidak dapat dihindari. Kenyataan ini terungkap dari hasil wawancara dengan informan yang mengatakan keresahannya dan kegelisahannya terhadap generasi muda yang saat ini yang kurang peduli terhadap kelestarian tradisi lisan Teda. Tradisi lisan Teda pada saat ini hanya dikuasai oleh penutur-penutur tua. Sementara itu, generasi muda seperti orang asing di negerinya sendiri. Generasi muda pada saat ini lebih tertarik dengan hal-hal yang berkaitan dengan teknologi seperti bermain gawai, gim daring, Facebook, dan lain-lain.

Menyadari berbagai kenyataan tersebut, upaya preservasi tradisi lisan Teda melalui ranah pendidikan dianggap sebagai langkah tepat-jika tidak menghendaki tradisi lisan, bahasa 
daerah, dan nilai-nilai kearifan lokal yang terekam dalam tradisi lisan menjadi punah. Upaya preservasi ini dapat dilakukan melalui ranah pendidikan formal baik ditingkat SD, SMP, SMA/SMK, maupun perguruan tinggi. Pada tingkat SD, SMP, dan SMA/SMK upaya preservasi dapat dilakukan melalui kegiatan kurikuler pada pelajaran Bahasa Indonesia dan muatan lokal, serta kegiatan ekstrakurikuler, seperti kelompok menyanyi, kelompok menari, dan teater.

Pada mata pelajaran Bahasa dan Sastra Indonesia, tradisi lisan Teda dapat dijadikan contoh konkret salah satu bentuk puisi lama yang sesuai dengan konteks budaya masyarakat Sumba. Selain itu, pada mata pelajaran muatan lokal tradisi lisan Teda dapat dijadikan pembahasan tersendiri dengan peserta didik diajarkan menuturkan Teda dan pengajar dapat memberi tahu secara eksplisit nilai-nilai yang terkandung dalam tradisi tersebut.

Penjelasan tersebut sejalan dengan preservasi melalui kegiatan kurikuler diatur dalam Permendikbud Nomor 79 Tahun 2014 Tentang Muatan Lokal. Pada Pasal 2 (1), dirumuskan bahwa muatan lokal merupakan bahan kajian atau mata pelajaran pada satuan pendidikan yang berisi muatan dan proses pembelajaran tentang potensi dan keunikan lokal yang dimaksudkan untuk membentuk pemahaman peserta didik terhadap keunggulan dan kearifan di daerah tempat tinggalnya. Selanjutnya, pada Pasal 2 (2) dirumuskan tujuan dari mata pelajaran Muatan Lokal, yakni untuk tujuan membekali peserta didik dengan sikap, pengetahuan, dan keterampilan yang diperlukan, yakni (a) agar peserta didik dapat mengenal dan mencintai lingkungan alam, sosial, budaya, dan spiritual di daerahnya, dan (b) agar peserta didik dapat melestarikan dan mengembangkan keunggulan dan kearifan daerah yang berguna bagi diri dan lingkungannya dalam rangka menunjang pembangunan nasional. Pada Pasal 4 (1) dirinci muatan dari mata pelajaran Muatan Lokal berupa (a) seni budaya, (b) prakrsa, (c), pendidikan jasmani, olahraga, dan kesehatan, (d) bahasa, dan (e) teknologi. Melalui pelajaran seni budaya, dapat diajarkan tradisi lisan Teda sebagai salah satu upaya untuk menjaga kelestarian tradisi tersebut.

Preservasi terhadap tradisi lisan Teda harus menjadi perhatian utama lembaga pendidikan formal. Meskipun dalam The McGill Conference In Honour of Wallace E. Lambert yang diedit oleh Allan G. Reynolds menyatakan bahwa pengembangan pemerolehan dan pembelajaran bahasa akan dapat berkembang secara lebih efektif bila diaplikasikan dalam kehidupan sosial. Akan tetapi, banyak pakar juga memberikan penekanan bahwa tipe pemerolehan bahasa secara formal mampu mendapatkan keluaran (output) yang lebih baik daripada pola naturalistik (Chaer, 1995). Tipe ini biasanya terjadi di dalam kelas dengan bimbingan seorang guru, materi, media, dan alat bantu pembelajaran yang sudah dipersiapkan secara baik. Aktualisasi dalam ruang lingkup pendidikan formal dapat dituangkan dalam kurikulum pembelajaran bahasa dan sastra berbasis lingkungan. Selain itu, pengajar juga dapat memilih metode pembelajaran yang dapat mengakomodasi kegiatan pembelajaran sehingga pembelajaran dan kegiatan esktrakurikuler tersebut dijiwai oleh semangat keataan, religius, persatuan, rekonsiliasi, dan tahu bersyukur. Hal ini selaras dengan peryataan Mbete (2015) bahwa pembelajaran bahasa yang diintegrasikan dengan ekologi dapat dijadikan muatan isi yang nyata dalam pembelajaran bahasa tentang lingkungan hidup. 
Selain kegiatan kurikuler, preservasi tradisi lisan dapat ditempuh melalui kegiatan ekstrakulikuler yang diberlakukan di jenjang sekolah dasar dan menengah seperti yang diatur dalam Permendikbud Nomor 62 Tahun 2014. Dalam Pasal 1, ekstrakulikuler didefinisikan sebagai kegiatan kurikuler yang dilakukan oleh peserta didik di luar jam belajar kegiatan intrakurikuler dan kegiatan kokurikuler, di bawah bimbingan dan pengawasan satuan pendidikan. Selanjutnya dalam Pasal 2, dipaparkan bahwa kegiatan ekstrakurikuler diselenggarakan dengan tujuan untuk mengembangkan potensi, bakat, minat, kemampuan, kepribadian, kerjasama, dan kemandirian peserta didik secara optimal dalam rangka mendukung pencapaian tujuan pendidikan nasional. Berdasarkan peraturan tersebut, upaya preservasi di sekolah dapat dilakukan dengan mendirikan kelompok minat dan bakat yang diikutsertakan berbagai unsur kebudayaan, serta didasarkan pada semangat kearifan lokal.

\section{PENUTUP}

Berdasarkan hasil penelitian dan pembahasan ditemukan bahwa dalam tradisi lisan Teda, khususnya pada upacara Padede Uma Kalada, terdapat lima nilai kearifan lokal yang selalu dihidupi oleh masyarakat Kabizu Beijello, yakni nilai ketaatan, religius, persatuan, rekonsiliasi, dan rasa syukur. Pada era globalisasi, nilai-nilai kearifan lokal yang dimiliki oleh komunitas etnik ini menjadi penting untuk dihayati dan dipelihara. Nilai-nilai luhur itu, apabila dihayati secara utuh dapat semakin memperkukuh dan memperkuat filosofi pancasila yang sudah mulai kehilangan jati dirinya karena tergerus arus globalisasi. Selain itu, nilai-nilai ini pula dapat bermanfaat dalam membina dan membentuk karakter peserta didik. Strategi preservasi tradisi lisan Teda melalui ranah pendidikan dapat dilakukan melalui kegiatan kurikuler dan kegiatan ekstrakurikuler, baik secara eksplisit menjadi sebuah mata pelajaran maupun secara implisit-dengan benarbenar menjiwai prosesnya.

\section{DAFTAR PUSTAKA}

Afiqoh, N., Atmaja, H. T., \& Saraswati, U. (2018). Penanaman nilai kearifan lokal dalam pembelajaran sejarah pokok bahasan perkembangan Islam di Indonesia pada siswa Kelas $\mathrm{X}$ IPS di SMA Negeri 1 Pamotan Tahun Ajaran 2017/2018. Indonesian Journal of History Education, 6 (1), 42-53.

Aluman, A. (2016). Perekonomian desa pada pelana masyarakat Sumba", G. Neonbasu (Ed.). Akar Kehidupan Masyarakat Sumba: dalam Cita Rasa Marapu. Jakarta: Lappop Press Jakarta.

Aslan. (2017). Nilai-nilai kearifan lokal dalam budaya pantang larang zuku Melayu Sambas". Jurnal Ilmu Ushuluddin, 16 (1), 11-20.

Asmaroini, A. P. (2017). Menjaga eksistensi Pancasila dan penerapannya bagi masyarakat di era globalisasi". Jurnal Pancasila dan Kewarganegaraan,1 (2), 50-64.

Badan Pengembangan dan Pembinaan Bahasa. (2016). Kamus Besar Bahasa Indoensia Daring. Diakses melalui https://kbbi.kemdikbud.go.id/entri 
Bera, Petrus, Ngogo, T. (2016). Spiritual capital dalam dinamika pembangunan dan ide kekerabatan, G. Neonbasu (Ed.). Akar Kehidupan Masyarakat Sumba dalam Cita Rasa Marapu. Jakarta: Lappop Press.

Chaer, A. dan L. A. (1995). Sosiolinguistik: Suatu pengantar. Jakarta: Rineka Cipta.

Dharmojo. (2005). Sistem simbol dalam Munaba Waropen Papua. Pusat Bahasa dan Departemen Pendidikan Nasional. Jakarta: Pusat Bahasa dan Departemen Pendidikan Nasional.

Duranti, A. (1997). Linguistic anthropology. New York: Cambridge University Press.

Endang, F. (2018). Preservasi, konservasi, dan restorasi bahan perpustakaan". LIBRIA, 10 (1), $13-32$.

Haugen, E. (1972). The ecology of language. California: Stanford University Press.

Hidayatullah, Riyan., Bambang Riadi, G. E. P. (2017). Transformasi tradisi lisan Lampung dalam seni pertunjukan: Perspektif pendidikan dan pewarisan budaya" dalam Prosiding Kegiatan Ilmiah Tingkat Nasional Kearifan Lokal dalam Dinamika Masyarakat Multikultural. Lampung: Lembaga Penelitian dan Pengabdian Kepada Masyarakat. Universitas Lampung.

Kami, K. (2018). Tradisi lisan Oka sebagai manifestasi jati diri masyarakat Wewewa Sumba Barat Daya: Kajian etnopragmatik. Tesis. Universitas Sanata Dharma.
Kartawinata. (2011). Merentas kearifan lokal di tengah modernisasi dan tantangan pelestarian. Kearifan Lokal di Tengah Modernisasi. Jakarta: Pusat Penelitian dan Pengembangan Kebudayaan.

Kompas. (2019). Cegah kematian bahasa. Diperoleh dari https://kompas.id/baca/utama/201 9/10/29/cegah-kematian-bahasa/

Mahsun. (2005). Metode penulisan bahasa: Tahapan strategi, metode, dan tekniknya. Jakarta: Rajawali Press.

Mbete, A. M. (2015). Pembelajaran bahasa berbasis lingkungan: Perspektif ekolinguistik. Retorika: Jurnal Ilmu Bahasa, 1 (2), 352-364.

Mulyadi. (2014). Ekologi bahasa dan metafora ekologis. Kumpulan Makalah. Seminar Nasional Ekolinguistik, 93-100. Medan.

Neonbasu, G. (2016). Tata krama relasi manusia dengan Marapu, G. Neonbasu (Ed.). Akar Kehidupan Masyarakat Sumba: dalam cita rasa Marapu. Jakarta: Lappop Press Jakarta.

Nugraha, M. T. (2019). Rekonsiliasi nilai-nilai kepahlawanan serta internalisasinya dalam pendidikan Islam. Jurnal Ta'dibuna, 8 (2), 241-258.

Primadesi, Y. (2013). Preservasi pengetahuan dalam tradisi lisan seni pertunjukan Randai di Minangkabau Sumatera Barat". Jurnal Kajian Informasi dan Perpustakaan, 1 (2), 179-187.

Rahardi, K. (2009). Bahasa prevoir budaya. Yogyakarta: Pinus Book Publisher. 
Rahardi, R. K. (2016). Urgensi menggelorakan linguistik ekologi. Kedaulatan Rakyat.

Rahardi, R. K., Setyaningsih, Y., \& Rishe Purnama Dewi. (2016). Kefatisan berbahasa dalam perspektif linguistik ekologi metaforis". Seminar Tahunan Linguistik, 1-6.

Ramone, R. (2015). Revitalisasi desa adat dan dampak sosial budaya masyarakat di Pulau Sumba. Jakarta: Direktorat Kepercayaan terhadap Tuhan YME dan Tradisi.

Shobihah, I. F. (2014). Kebersyukuran (Upaya membangun karakter bangsa melalui figur ulama). Jurnal Dakwah, 2 (15), 383406.

Spradley, James, P. (2007). Metode etnografi (Kedua). Yogyakarta: Tiara Wacana Yogya.

Sriyono. (2014). Kearifan lokal dalam sastra lisan suku Moy Papua". Jurnal Atavisme, 17 (1), 55-69.

Steffensen, Sune, V., \& Fill, A. (2013). Ecolinguistics: The state of the art and future horizons". Language Sciences, 1-20.

Sudaryanto. (2015). Metode dan Aneka Teknik Analisis Bahasa: Pengantar Penelitian Wahana Kebudayaan secara Linguistis. Yogyakarta: Sanata Dharma University Press.
Sukmayadi, T. (2018). Nilai-nilai kearifan Lokal dalam pandangan hidup masyarakat adat Kampung Kuta". Jurnal Pancasila Dan Kewarganegaraan, 1 (3), 1929.

Supriatin, Yeni, Mulyani. (2012). Tradisi lisan dan identitas bangsa: Studi kasus kampung adat Sinarresmi, Sukabumi. Balai Pelestarian Nilai Budaya Bandung, 407418.

Takari, M. (2013). Tradisi lisan di alam Melayu. Fakultas Ilmu Budaya. Universitas Sumatera Utara https://doi.org/10.13140/RG.2.2. 27442.91845

Uyanne, C. M., Onuoha, E. C., \& Osigwe, N. A. (2014). Ecolinguistic perspective: Dialectics of language and environment". AJELLS, 5 (1), $150-169$.

Wirajaya. (2016). Preservasi dan konservasi naskah-naskah Nusantara di Surakarta sebagai upaya penyelamatan aset bangsa". Jurnal Etnografi, 2 (16), $59-123$. 